\title{
Incidence of mungbean yellow mosaic virus (mbymv), its epidemiology and management through mycotal, imidacloprid and tracer
}

\author{
Muhammad Aslam Khan ${ }^{1}$, Abdul Rashid ${ }^{1}$, Abdul Mateen*1, Muhammad Sajid ${ }^{1}$, Farhan \\ Rasheed $^{2}$, Muhammad Aqeel Anjum ${ }^{3}$, Ayesha Anjum ${ }^{4}$, Muhammad Fayyaz ${ }^{5}$, \\ Muhammad Farooq ${ }^{6}$. \\ ${ }^{1}$ Department of Plant Pathology, University of Agriculture, (38000) Faisalabad. \\ ${ }^{2}$ Department of Crop Physiology, University of Agriculture, (38000) Faisalabad. \\ ${ }^{3}$ University of Lahore, (54000) Lahore. \\ ${ }^{4}$ Medical Social Officer, Department of Social Welfare and Bait UI Mal Punjab, (54000) \\ Lahore. \\ ${ }^{5}$ Pest Warning and Quality Control of Pesticieds, (54000) Lahore. \\ ${ }^{6}$ Pest Warning and Quality Control of Pesticieds, (52250) Gujranawala. \\ Corresponding Author: Abdul Mateen, M.Phill (Agriculture), Plant Pathology, \\ a-mateen@hotmail.com
}

\begin{abstract}
Four varieties of mungbean AARI-2006, Mung-97001, NM-2006 and M-6 were subjected to screening in the Research Area of Department of Plant Pathology, University Of Agriculture Faisalabad. Three chemicals Imidacloprid, Mycotal and Tracer were evaluated against mungbean yellow mosaic virus (MBYMV) and whitefly. The variety AARI-2006 was resistant while the variety NM-2006 was moderately resistant. The chemical imidacloprid was most effective to control whitefly population and MBYMV. Correlation of environmental factors (maximum and minimum temperature, relative humidity and rainfall) with MBYMV percent plant infection was also determined. There was a significant correlation of environmental variables with MBYMV percent plant infection. The use of Imidacloprid proves to be a best option in case of epidemiological occurrence of environmental variables followed by Tracer and Mycotal respectively.
\end{abstract}

Key words: Mungbean Yellow Mosaic Virus (MBYMV), Mungbean Disease, Insecticide, Mungbean (Vigna radiata L.), Correlation.

\section{INTRODUCTION}

Mungbean (Vigna radiata L.) belongs to the family Fabaceae. This is an ancient, cheapest and conventional pulse crop in the world. It is also called as green gram. The crop being Asiatic in origin was introduced during early $18^{\text {th }}$ century in south China, Indo China and Java. For the last three decades, the crop has been cultivated in south half of Asia including Pakistan, India, Burma, Thailand and Philippine [5]. Later, on the crop was introduced to East and Central Africa, West Indies and US [7]. It is a popular crop with high nutrient value. It contains $20-24 \%$ protein, $60-65 \%$ carbohydrates and $2.69-5.80 \%$ sugar contents [4]. It is an excellent component of human diet particularly for peasants of under developed countries where, animal protein is not easily available and affordable. Mungbean is cultivated during summer as well as spring season in Pakistan. It is grown on area of 183.3 thousand hectare with annual production of 118.7 thousand tons [1]. It is considered as second most important pulse after chick pea in Pakistan but its average yield in our country is very low as compared to other countries. This is because of many reasons such as traditional methods of cultivation, low yielding varieties, lack of irrigation facilities [9] and particularly the occurrence of disease. Although this crop is affected by various pathogens but Mungbean Yellow Mosaic Virus is the most important and distributed throughout the Pakistan. MBYMV causes irregular yellow and green patches on older leaves and complete yellowing leaves. Affected plants produce less number of pods and flowers and few seeds. 
Mungbean is also affected by a dozen of insect pest such as pod borer, leaf miner, jassids, foliage caterpillar, cut worm, aphids and white fly [2]. White fly (Bemisia tabaci) is very important because it acts as vector for the transmission of MBYMV.

The insecticides have been used for the management of whitefly without taking the consideration of environmental conditions. Epidemiological factors play crucial role in the development of MBYMV and white fly population. The correct time of application of insecticides can be helpful not only to manage whitefly and virus but also to minimize the number of sprays. The study of epidemiological factors determined the most conducive environment for the application of pesticides at right time thus, enhancing the yield of this crop. The objective of this study is to evaluate the effect of Mycotal, imidacloprid and tracer against MBYMV and population of white fly.

\section{MATERIALS AND METHODS}

Collection of Varieties and Sowing: Germplasm of Mungbean was obtained from Ayub Agriculture Research Institute, Faisalabad. Experiment was conducted during 2009-2010, in the experimental area of Department of Plant Pathology, University of Agriculture Faisalabad. The four Mungbean genotypes viz. Mung-97001 (V1), M-6 (V2), AARI2006 (V3), NM-2006 (V4) were cultivated. The row to row distance was $30 \mathrm{~cm}$ and plant to plant spacing was $5 \mathrm{~cm}$, after three rows of test line single line of local susceptible check variety is grown to serve as spreader. The experiment was conducted according to Randomized Complete Block Design, with three replications.

Application of Fungicide: Mycotal, Tracer and Imidacloprid were applied to manage the whitefly population and MBYMV. The data of MBYMV and its vector as influenced by Mycotal, Tracer and Imidacloprid treatments was recorded. Severity of infection was evaluated according to a scale studied [13].

Collection of Environmental data: Environmental data like temperature, humidity and rainfall was taken from meteorological station of Department of Crop Physiology, University of Agriculture Faisalabad. Relationship of epidemiological factors with percent plant infection of MBYMV and whitefly density through correlation and regression was determined. Effect of treatments on the yield of Mungbean was determined through ANOVA and LSD test [12].

\section{RESULTS}

Response of Mungbean varieties/lines to MBYMV: None of the varieties/lines showed immune to MBYMV and Bemisia tabaci. The variety Aari-2006 was resistant while, Mung-97001 and M-6 showed moderate susceptibility. The variety NM-2006 showed moderate resistance (Table.1).

Table.1: Summary statement of varieties exhibiting various Levels of resistance/susceptibility based on $\%$ plant infection.

\begin{tabular}{|c|c|c|c|c|}
\hline Sr. No & Cultivars & $\%$ Plant infection & Severity rating & $\begin{array}{c}\text { Level of } \\
\text { resistance/susceptibility }\end{array}$ \\
\hline 1 & Mung-97001 & 22.99 & 3 & Moderately Susceptible \\
\hline 2 & AARI-2006 & 5.96 & 1 & Resistant \\
\hline 3 & M-6 & 22.01 & 3 & Moderately Susceptible \\
\hline 4 & NM-2006 & 13.31 & 2 & Moderately Resistant \\
\hline
\end{tabular}

Effects of treatments on Mungbean Yellow Mosaic Virus percent plant infection: The effect of all the treatments was significant on MBYMV infection. Mean number of the infected plants by MBYMV was significantly higher in untreated control followed by Mycotal and Tracer. The most effective treatment was imidacloprid (Table.2).
Table.2: Comparative means of treatments

\begin{tabular}{|c|c|}
\hline Treatments & $\begin{array}{c}\text { MBYMV \%plant } \\
\text { infection }\end{array}$ \\
\hline T1 (Imidacloprid) & 11.72 \\
\hline T2 (Tracer) & 17.06 \\
\hline T3 (Mycotal) & 20.21 \\
\hline T4 (Control) & 24.61 \\
\hline L. S. D & 1.23 \\
\hline
\end{tabular}


Effect of treatments on whitefly population: All the treatments reduced the whitefly population. The whitefly population was high at untreated control while, it was low where Imidacloprid was applied (Table.3).

Table.3: Comparative means of treatments for whitefly

\begin{tabular}{|c|c|}
\hline Treatments & $\begin{array}{c}\text { Whitefly population } \\
\text { (per leaf) }\end{array}$ \\
\hline T1 (Imidacloprid) & 1.68 \\
\hline T2 (Tracer) & 2.37 \\
\hline T3 (Mycotal) & 3.60 \\
\hline T4 (Control) & 7.59 \\
\hline L. S. D & 0.27 \\
\hline
\end{tabular}

Correlation of Environment with percent plant infection by MBYMV: All varieties responded differently to temperature (maximum/minimum), relative humidity and rainfall. The relationship of these environmental parameters with percent plant infection by MBYMV on most varieties was positive except for maximum temperature and it was best explained by linear regression as indicated in figures.

The correlation of maximum temperature with percent plant infection for all varieties was non significant. There was a negative correlation between maximum temperature and percent plant infection. With increase in maximum temperature from 36.5 to $38.5^{\circ} \mathrm{C}$ the percent plant infection was decreased (Fig.1).

$$
\begin{array}{ll}
\text { V1=30.82-1.75x } & r 1=-0.64^{*} \\
\text { V2=28.89-0.32x } & r 2=-0.58^{*} \\
\text { V3=15.12-1.43x } & r 3=-0.63^{*} \\
\text { V4=08.72-0.81x } & r 4=-0.62^{*}
\end{array}
$$
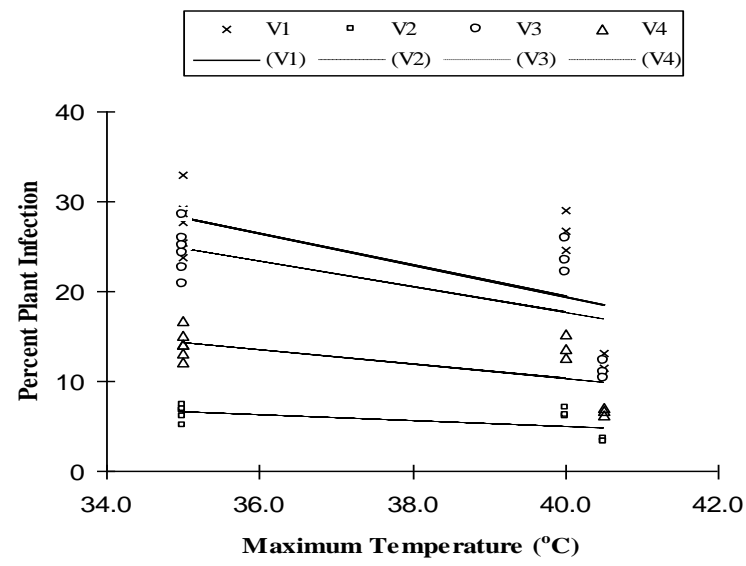

Fig.1: Correlation of maximum temperature with MBYMV percent plant infection

The correlation of minimum temperature with percent plant infection was highly significant as with increase in minimum temperature percent infection also increase. The correlation was explained by linear regression model as indicated by $0.94,0.91,0.94$ and $0.93 r$ values respectively (Fig.2).

$$
\begin{array}{ll}
\mathrm{V} 1=9.65+3.12 x & \mathrm{r} 1=0.94^{\star *} \\
\mathrm{~V} 2=8.63+0.61 x & \mathrm{r} 2=0.91^{\star *} \\
\mathrm{~V} 3=6.45+2.61 x & \mathrm{r} 3=0.94^{\star *} \\
\mathrm{~V} 4=2.21+1.47 x & \mathrm{r} 4=0.93^{\star *}
\end{array}
$$

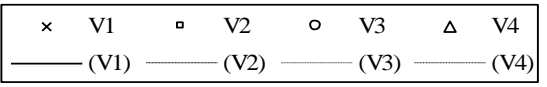

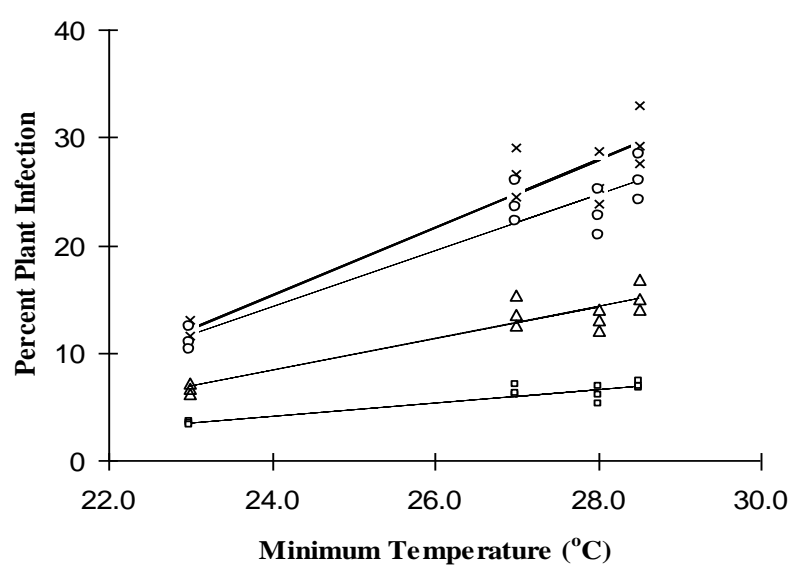

Fig.2: Correlation of minimum temperature with MBYMV percent plant infection 
The correlation of relative humidity with percent plant infection was positive. Correlation was significant except on Mung-97001 where, it was non significant. The linear regression model as indicated by 0.48 , $0.52,0.50$ and $0.49 r$ values (Fig.3).

$$
\begin{array}{lll}
\mathrm{V} 1=2.20+0.41 x & \mathrm{r} 1=0.48^{\mathrm{NS}} \\
\mathrm{V} 2=0.98+0.09 x & \mathrm{r} 2=0.52^{*} \\
\mathrm{~V} 3=2.39+0.35 x & \mathrm{r} 3=0.50^{*} \\
\mathrm{~V} 4=1.56+0.20 \mathrm{x} & \mathrm{r} 4=0.49^{*}
\end{array}
$$

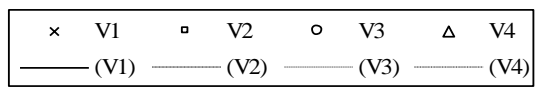

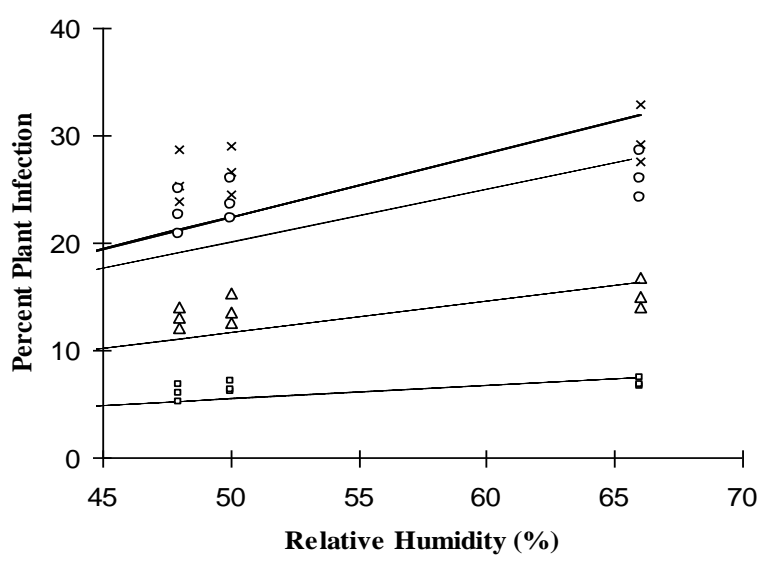

Fig.3: Correlation of relative humidity with MBYMV percent plant infection

The correlation of rainfall with percent plant infection was positive and significant for all the varieties. Correlation was explained by linear regression model as indicated by $0.56,0.58,0.67$ and $0.54 r$ values respectively (Fig.4).

$$
\begin{array}{lll}
\mathrm{V} 1=22.66+0.46 x & \mathrm{r} 1=0.56^{*} \\
\mathrm{~V} 2=5.45+0.11 x & \mathrm{r} 2=0.58^{*} \\
\mathrm{~V} 3=20.14+0.42 x & \mathrm{r} 3=0.67^{*} \\
\mathrm{~V} 4=11.67+0.23 x & \mathrm{r} 4=0.54^{*}
\end{array}
$$
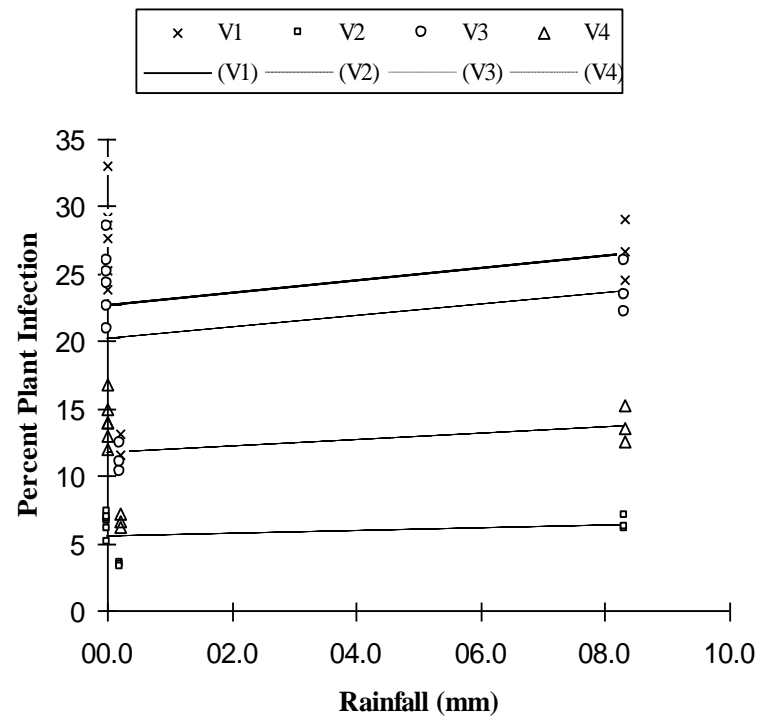

Fig.4: Correlation of rainfall with MBYMV percent plant infection

\section{DISCUSSION}

Mungbean varieties were affected by the disease and whitefly in early growth stages. No variety was highly resistant to MBYMV. Variety AARI-2006 was resistant while, NM-2006 exhibit moderate resistance. The other two varieties M-6 and Mung97001 were moderately susceptible towards Mungbean Yellow Mosaic Virus. The experiment was conducted for screening of Mungbean germplasm for Mungbean Yellow Mosaic Virus infection [3]. None of the cultivar evaluated was found to be immune or highly resistant to MBYMV disease. Evaluation of mungbean ( $V$. radiata) germplasm consisting of 254 lines against mungbean yellow mosaic Begomo virus (MBYMV) under natural field conditions conducive for development of disease and whitefly virus vector population [10]. Whitefly population, ranged between 1.5-8 adults/plant with an average of 4 adults. Mungbean yellow mosaic virus occurred over a wide range of climatic conditions in summer. None of the lines appeared to be resistant of any category, 7 lines were classified as susceptible and 247 as highly susceptible.

All varieties responded differently to temperature (maximum/minimum), relative humidity and rainfall. The relationship of these environmental parameters with percent plant infection by MBYMV on most varieties was positive. Studied was done on the effect of epidemiological factors on the incidence of MBYMV [11]. 
Imidacloprid was more toxic to pest compared with others followed by Tracer and Mycotal. These findings were in agreement with those of who studied $B$. tabaci management to prevent the honey dew contamination. He developed a program with special reference to the control of $B$. tabaci with the use of Imidacloprid, Buprofezin and Diafenthiuron [6]. Evaluation in U.K. was done on Imidacloprid for the control of B. tabaci [8].

\section{CONCLUSION}

According to observed results we can conclude that the decreasing rate of maximum temperature range and increasing rate of minimum temperature range, relative humidity and the rain fall cause increase in plant infections by increasing pathogen population. It indicates that the optimum temperature for infect at 28-35 ${ }^{\circ} \mathrm{C}$. While, for management of pathogen vector (Bemisia tabaci) and MBYMV the treatments of Imidacloprid was proved to be most effective followed by Tracer and Mycotal respectively. It was also concluded that with the increasing temperature, relative humidity and rain fall the disease may cause economic losses and in these epidemiological conditions the use of Imidacloprid was best option in Mungbean.

\section{REFERENCES}

[1] Anonymous. Economic survey of Pakistan 2010, Finance Division, Economic Advisory Wing, Islamabad. 2010. pp. 22.

[2] A.S. Atwal. Agriculture Pest of India \& South East Asia. Kalyani Publisher, Ludhiana, 1994.

[3] A. Ayyub. Studies on the screening of mungbean germplasm and growth responses of mungbean plant to mungbean yellow mosaic virus infection. M.Sc. Thesis Dept. Plant Pathology, Uni. Agri. Faisalabad. 1987. Pp. 67-70.

[4] A.E. Bender. Nutrition and dietic foods chemical publishing co, inc., New york, U.S.A. 1973.
[5] A.D. Duke. Hand book of legumes of World Economic Impact. 1st. Edtition. Plenum Press, New York \& London. 1981. Pp. 293-296.

[6] G. Forer. White fly management in Israel to prevent honey dew contaimination. Intl. Cotton Adv. Comm., 33-37. 1990. Rev. Agric. Entomol., $81: 7126$.

[7] J.M. Martin, W.H. Lionard and D.L. Stamp. Principles of field crop production. Macmillan Pub. Co. inc. New York. 1976. Pp.672-678.

[8] R.D. Oetting and AIL. Anderson. Imidacloprid for control of whiteflies on greenhouse grown poinsettias. 1991. Brighten Crop. Pro. Conf.,I:367-372 Rev.Agric. Entomol., 79:9189.

[9] I. Sekar and Badal, P.S. Socio-Economic analysis of Mungbean in India. Collabortive project repot on Asian vegetable research and development center No. 88-292. Shanhua, Tainan, Taiwan 741, Repulic of China (ROC). Asian vegetable research and development center. 2001. Pp. 20.

[10] N. Shad, S.M. Mughal, K. Farooq and M. Bashir. Evaluation of Mungbean germplasm for resistance against mungbean yellow mosaic begomovirus. 2004. Pakistan. J. Bot. 38:449-457.

[11] A. Shafqat,. Study on the evaluation of insecticides/Biopesticides against mungbean yellow mosaic virus and its vector in relation to epidemiological factors. M.Sc. Hons thesis dept. PI. path. Univ. Agric. Faisalabad. 2005. Pp.20.

[12] R.G.D. Steel, J.H. Torrie and D.A. Deekey. Principles and procedures of Statistics. A biometrical approach. 3rd Ed. McGraw Hill Book Co., Inc., NY, USA. 1997.

[13] M. Zafar. Study on determination of resistant source against Mungbean yellow mosaic virus and evaluation of plant extract for its management. M.Sc Hons thesis deptt. PI. Path. Univ. Agric. Faisalabad. 2007. Pp.30. 